Article

\title{
Spatial Economic Convergence and Public Expenditure in Ecuador
}

\author{
Jorge Flores-Chamba ${ }^{1}\left[\right.$, Ronny Correa-Quezada ${ }^{2}$, José Álvarez-García ${ }^{3, *} \mathbb{i}$ and \\ María de la Cruz del Río-Rama ${ }^{4}$ (i) \\ 1 Department of Economics, Universidad Nacional de Loja (UNL), 11-01-11 Loja, Ecuador; \\ jorge.flores@unl.edu.ec \\ 2 Department of Economics, Universidad Técnica Particular de Loja (UTPL), 11-01-608 Loja, Ecuador; \\ rfcorrea@utpl.edu.ec \\ 3 Financial Economy and Accounting Department, Faculty of Business, Finance and Tourism, \\ University of Extremadura, 10071 Caceres, Spain \\ 4 Business Organisation and Marketing Department, Faculty of Business Administration and Tourism, \\ University of Vigo, 32004 Ourense, Spain; delrio@uvigo.es \\ * Correspondence: pepealvarez@unex.es; Tel.: +34-927257968
}

Received: 28 December 2018; Accepted: 21 January 2019; Published: 23 January 2019

\begin{abstract}
In Ecuador, the sectorial policies, public policies and state investment, increase the presence of polarized and polycentric territories with very heterogeneous characteristics and with asymmetric levels of economic growth and development. The explanation for the unequal growth of regions in Ecuador is determined by the existence of different types of asymmetries; that determine economic dynamics and non-convergent development processes. The aim of this research is to determine the effect of an increase in public spending on physical infrastructure and education, on the improvement of productive conditions and on the process of reducing disparities (convergence) at the regional level in Ecuador. To do this, the hypothesis of beta convergence will be tested, which is conditioned by the proxy variables of public expenditure or investment in infrastructure and education at provincial level, for the 2001-2015 period. The results show the existence of a "slight" process of convergence per capita and productivity, although with a significant level of territorial "segregation". In the same way, it is observed that public investment made in this period did not increase the productivity of small and medium-sized provinces significantly, severely conditioning the sustainability of the process of reducing disparities at regional level.
\end{abstract}

Keywords: public expenditure; regional disparities; economic convergence; beta convergence; reprimarization

\section{Introduction}

By considering space as one of the determining factors of economic activity behaviour enables us to understand the reason for an unequal growth of the territories that make up a nation. It is important to point out that there are "natural" circumstances that drive the growth of regions, related to their location, their endowment of natural resources, skilled and unskilled labour and productive infrastructure, etc. However, external factors such as economic globalization, technological development and the "orientation" of the economic policy change these conditions, favouring the re-emergence of traditional economic sectors or the development of "innovative" economic activities that affect not only the sectorial structure of employment but also the growth of territories. These elements must be analysed in depth to understand the processes of concentration, agglomeration and growth of certain branches of economic activity and regions. 
The explanation for the unequal growth of regions in Ecuador is determined by the existence of different types of asymmetries; that determine economic dynamics and non-convergent development processes. As Correa-Quezada [1] indicates, given the historical process of accumulation of the neoliberal model and its dependent articulation on the world market, it has been determined that sectorial policies, public policies and state investment, especially in infrastructure, in turn increase the presence of polarized and polycentric territories with very heterogeneous characteristics and with asymmetric levels of economic growth and development.

In the period from 2007 to 2014, Ecuador obtained extraordinary income due to the rise in oil prices in international markets, which in turn allowed for considerable public investment in infrastructure and education. These are key elements for production processes and for improving individuals' quality of life, so it is necessary to carry out research that analyses their effects on growth and development [2].

Although there are several studies in Latin America that evaluate the importance of the infrastructure that the state provides for growth [3-6] and for Ecuador [7-9]; they do not take into account that public funding takes place in a territory composed of economically disparate regions, with different degrees of affectation; and whether this element could contribute to the reduction of regional asymmetries.

In this context, this article analyses the disparities related to income and productivity of Ecuadorian provinces in the 2001-2015 period, considering public expenditure on education and infrastructure as determining factors. The methodology used to achieve the proposed objective is based on testing the convergence hypothesis by econometric estimations of Panel Models and Spatial Fixed Effects Models, both for the calculation of the convergence of provincial per capita income and of regional productivity.

The structure of this article is defined as follows. In the introduction, the subject is contextualized and the objective is stated, then in the theoretical framework, reference is made to convergence and endogenous growth models that determine it, as well as the importance of human capital and investment in public infrastructure in regional development. This section ends by mentioning the studies and empirical evidence corresponding to the topic in question. In the third section the methodology, the data and the econometric specification of conditional beta per capita and in productivity are discussed. The results of the fixed effect panel and spatial fixed effect panel models are presented and analysed in the fourth section. Finally, the conclusions, recommendations and limitations of the investigation are presented.

\section{Theoretical Framework}

\subsection{Economic Convergence and Growth}

Economic convergence mainly studies the internal or "endogenous" factors of the productive process. In this sense, the accumulation of productive factors: labour, physical capital and human capital explain the differentials of growth and economic convergence between nations or regions. The origins of the growth theory are found in the contributions by Solow [10] and Swan [11]. The Solow Growth Model states that although the product grows in the long term, the reduction of the marginal productivity of physical capital causes a reduction in the incentive to invest, in the same sense as the contribution of capital to the product, inhibiting the very process of economic growth. According to this model, an economy converges according to a certain dynamics to a steady state or equilibrium, depending on its level of technology, its savings rate and the growth rate of its population.

The phenomenon of economic convergence occurs due to the existence of diminishing returns of the physical capital factor that affects the per capita product levels of economies. The model proposes a Cobb-Douglas neoclassical production function.

$$
Y=F(A, K, L)=A K^{\infty} L^{\beta}
$$


where $Y$, is the level of production of an economy; $K$ and $L$ are the quantities of physical capital (cumulative) and labour factors used, respectively; $A$, is an index of technological level, that within the model is constant (the technology does not grow as time goes by); $\alpha$ and $\beta$ are the product elasticities with respect to each of the productive factors.

Subsequently, in order to explain better the positive and prolonged growth registered by the main economies of the world, especially in the United States in the 1950s and 1960s, some improvements were introduced in the Solow model. Thus, technological progress was included in the production function (which grows at an exogenous rate) and the possibility of increasing or constant returns to scale of productive factors. The only possibility of product growth is given by the growth rate of technological progress. In this context, changes in the level of the savings rate or in the level of the production function affect the stationary levels of the variables, but not their long-term growth rates, given that the investment rate will not affect the technological progress rate.

According to Mora [12], Solow's "neoclassical" model implies economic convergence between territories, since it assumes that poor economies have many investment opportunities and show high interest rates, encouraging consumer savings and obtaining higher growth rates than those of rich territories, whose growth process is slowed down by the diminishing returns of their accumulated physical capital. In the long term, both groups of economies tend to share a growth "path".

On the other hand, given that the growth rate of the per capita product is proportional to the growth rate of per capita capital, the model predicts a negative relationship between the initial per capita product and the corresponding growth rate of the period analysed, and the convergence to a single steady state, the so-called absolute convergence. However, convergence conceived in this way implies very restrictive assumptions such as initial stocks of similar capitals and equality in the growth rates of the technological progress. These weaker assumptions allow for the appearance of the convergence of each economy to its own steady state, depending on its initial endowments of productive factors and the conditioning variables of its growth, the so-called conditional convergence.

\subsection{Endogenous Growth Models}

These models developed in the last decade of the 80 s and early 90 s by Romer $[13,14]$ and Lucas [15] pose a situation of sustained growth and lack of convergence to a steady state in the long term. They discard the presence of diminishing returns in productive factors and aim to "endogenize" the mechanisms that cause sustained growth.

The first approximation of this contribution is found in the work by Arrow [16], which emphasizes the role of externalities related to capital accumulation. Endogenous growth models are basically differentiated by the cumulative factor that contributes to growth: physical capital (with learning effects), technology (R \& D), human capital, infrastructures and basic services. In addition, they accept the existence of non-constant scale returns and imperfect competition.

Following the explanation by Van der Ploeg and Tang [17], endogenous growth models are classified into: learning accumulation models by practice, capital accumulation models and public infrastructure accumulation models. For this research paper, the second (investment in human capital) and third group of models will be considered, given the interest in measuring the effect of increasing public expenditure on education and infrastructure in the growth process of Ecuadorian regions.

\subsubsection{The Accumulation of Human Capital}

This model arises from the "explicit" inclusion of technology in the model proposed by Rebelo [18] and the differentiated treatment of the types of capital in the production function, considering human capital as the sum of capabilities that generate productive efficiency and that are "incorporated" to individuals.

Lucas [15] proposes the idea that the accumulation of human capital generates positive externalities for "contiguous" economic agents. The model formally presents two sectors. The first one produces final goods intended for consumption and requires the use of capital, both physical 
and human; while the second one is education aimed at the production and accumulation of human capital. The production function of the Cobb-Douglas type for the first sector shows constant returns to scale with respect to physical capital and increasing returns to human capital and has the following mathematical expression:

$$
Y=A K^{\alpha}(u h L)^{1-\alpha} h_{a}^{\varphi}
$$

where $Y$, is the production level of the final goods sector; $K$ and $L$ are the quantities of the physical capital and labour factors used, respectively; A, is the productivity of the final goods sector; $u$ is the fraction of time that individuals work in the production of final goods; $h$ is a measure of the average qualification of workers; $u h L$, is the total effective work adjusted by its quality and $h^{\varphi}{ }_{\alpha}$ collects the externality of the average stock of human capital, being $h_{\alpha}$ he average human capital of the set of individuals.

With regard to the production function of the education sector (3), the term $(1-u)$, is the time devoted to the accumulation of skills or qualifications; the term $\varphi$ corresponds to the productivity of the education sector and $\delta_{h}$ to the depreciation of human capital, considering $\mathrm{h}$ as the only factor in the production of human capital. Therefore, the production function of human capital $\left(Y_{E}\right)$ is as follows:

$$
Y_{E}=\varnothing h(1-u)
$$

In the model, the relevant productivity parameter for economic growth is the productivity index of the education sector $(\varphi)$, instead of the productivity index of the final goods sector $(A)$, due to the multiplying effect of production of human capital in the production function of the final goods sector. One of the implications of this model is that the sector that can be considered an engine for growth of an economy is one where human capital with a high qualification level is generated.

\subsubsection{The Incidence of Public Infrastructure}

Another growth source in endogenous models is public goods and infrastructure. These goods and services increase the productivity of private factors due to the possibility of massive and simultaneous use. Therefore, the production function is extended to collect this "positive" influence of the State, considering a single factor: capital, although differentiating it in private and public $(g)$. The expression of the aggregate function is as follows:

$$
Y=f(k, g)=A k^{\alpha} g^{1-\alpha}
$$

where $Y$, is the level of aggregate production; $K$, is the amount of private capital used; $g$, is the amount of public capital used; $A$, is the productivity of capital (public and private); $\alpha$ is the elasticity of the product with respect to private capital and $1-\alpha$ is the elasticity of the product with respect to public capital.

Considering what has been stated, it can be mentioned that endogenous growth models do not predict a phenomenon of economic convergence between regions because they assume the existence of imperfect competition that prevents equal conditions in the access to technology, the non-existence of diminishing returns in the accumulation of physical capital and lack of balance in the final goods market, leading to differentiated growth trajectories between countries and regions. In any case, these theoretical concepts consider the possibility of the existence of differentiated growth behaviour between groups of countries or regions, that is, they recognize the presence of convergence towards several steady states, determined by the degree of heterogeneity of the economies analysed.

In recent years, in Latin America, awareness of the importance of State participation in development processes has been regained, in particular to improve opportunities in territories or regions that show clear economic and social disadvantages. There are many public policies that are used, one of the most widespread being investment in infrastructure, mainly roads, electricity and drinking water [19]. According to Bustillos, Alonso and Gutiérrez [20], several authors stand out for 
their contributions regarding the importance of government intervention and its investment in the economy, among them Harrod [21], Domar [22], Kaldor [23], Hicks [24] and Robinson [25,26].

Infrastructures were incorporated into the growth theory by Arrow \& Kurz [27] and Weitzman [28] in 1970. However, the subject began to be studied in greater depth [29] since Barro [30]. In this sense, public spending is considered by Barro [30] as one of the elements that generates endogenous growth. According to Sánchez [5] (p. 27), in economic growth theories, the role of investments in infrastructure is considered fundamental. Barro and Sala-i-Martín [31] find in their economic growth model that the inclusion of infrastructure indicators on the right hand side of their equations has positive effects on product growth. These premises are also shared by Wadley [32], who indicates that transport and communications infrastructures, urban structures, as well as physical capital and human capital can favour regional development.

The transport infrastructure derived from state investment generates positive effects and clusters of companies and individuals [33-36]. Along the same lines, Rostow [37], in a pioneering work published in 1961, claimed that the development of infrastructure networks, particularly transport networks, was an essential precondition for economic development. This idea was supported by Taafe et al. [38], who stated that public infrastructure conditioned the pace of the aggregate growth of the economy and evaluated the direct impact of the former on the latter. While for Barro [39], infrastructure facilitates the circulation of information, goods and people, which in turn leads to the productivity of companies in regions.

\subsection{Empirical Evidence}

Although asymmetries, growth models and convergence have been studied in different continents, regions and countries; in this section we will describe in a general way the studies that have been carried out in Latin America, cases and evidence that are closer to this case study, being the regions of Ecuador, and focused on the contributions that incorporate education and public investment as determinants of regional growth.

In the 90 studies on convergence among Latin American countries, there has been evidence since they began that convergence processes have taken place, by highlighting the role of education and public investment in growth [40-42]. Years later, Mendoza [43] shows a process of convergence of Latin American economies in the 1950-1975 period and the existence of a phenomenon of divergence in the 1980-2000 period, derived from the reduction of public expenditure and a significant increase in openness to trade.

Martín [44] also performs a study of the evolution of the per capita income disparities of 18 Latin American countries in the 1950-2008 period. This author concludes that there is no spatial dependence in the estimated model; but there is a beta convergence process of the countries. Concerning the "dynamics" measurement of convergence, Rodríguez, López and Mendoza [45] tested the convergence hypothesis of the GDP per capita in a sample of 17 Latin American countries in the 1951-2010 period, providing evidence of conditional convergence processes.

In relation to national studies developed in countries, in Argentina, Utrera and Koroch [46] find evidence of conditional convergence when using human capital variables, in the same country Garrido, Marina and Sotelsek [47] reach the same conclusion incorporating the additional variables of education and public expenditure. Whereas in Colombia divergence was observed for the period 1960 and 1995, possibly due to a difference in the capacity to form economies of scale, the level of public investment and other variables [48].

For the regions of Chile (period 1960-1992 and 1980-1992), Morandé, Soto and Pincheira [49] carry out an analysis with the methodologies of Barro and Sala-i Martin [50], Bernard and Durlauf [51] and Canova and Marcet [52]. There is evidence of absolute convergence, with a 2.3\% speed for 1960-1992. By incorporating different variables such as schooling, level of extreme poverty, participation of primary activities in the Gross Domestic Product (GDP) and public sector investment, they find a convergence rate of 4.8\% for the 1980-1992 period (cited by Willington [53] (p.21)). Also in Chile, 
Chacón and Paredes [54] confirm that human capital is not distributed randomly in space but that its concentration in large urban centres has a significant effect on the inequality of income between communes in the 1992-2011 period.

The accumulation of physical capital can influence the growth and convergence processes of regions. This conclusion was reached by Vergara, Mejía and Martínez [55], when they analysed the impact of basic and social infrastructure investment on the growth of the State of Mexico in the 1989-2004 period. In this area, the importance of physical infrastructure in the economic growth of the municipalities of the northern border is addressed by Bustillos, Alonso and Gutiérrez [20].

Mendoza and Valdivia [56] determine in their study that regional economic growth in Mexico is partly explained by a beta convergence process with heterogeneity and strong spatial dependence, and by the variations of the variable: years of average schooling; and that remittances as a share of regional GDP have a higher impact on the convergence of the 2001-2008 period.

In the case of Ecuador, there are no convergence studies that relate it to human capital or investment. However, it is necessary to mention studies whose aim was to measure convergence and territorial disparities at provincial level, Ramón-Mendieta, Ochoa-Moreno and Ochoa Jiménez [57]; Ramón-Mendieta and Quintana [58]; Quintana, Mendoza and Correa-Quezada [59]; and CorreaQuezada [1], at cantonal level Mendieta-Muñoz [60]; and, Aguilar and Correa-Quezada [61].

\section{Methodology and Data}

The fundamental problem of estimating convergence is to establish whether the economy operates under an "automatic" mechanism or process of convergence in terms of per capita income (employed), or if, on the contrary, regional disparities are emphasized. In this context, an analysis is made of the relationship between the growth rate and the level of initial income, conditioned by "determinant" variables of the steady state, in this specific case some explanatory variables related to public expenditure and a variable that "measures" the "structural change".

In Sala-i-Martín [62], it is pointed out that the study of economic convergence in the sense of a steady-state approximation emerged as a fundamental test to distinguish between new endogenous growth models of the early $90 \mathrm{~s}$ and the traditional models of exogenous growth based on Solow [10] and Swan [11]. On the other hand, it is shown that these models enable to quantify the "speed" at which economies evolve during their transition towards the steady state.

Conditional beta convergence analyses the degree to which poor economies grow more rapidly than rich ones, which implies that they have a common steady state (different from that of rich economies). The existence of $\beta$ convergence is observed when there is a negative relationship between the growth rate of the product or per capita income and the initial level of that product, that is, it implies finding a negative and statistically significant coefficient for $\beta$ in a linear relationship between the growth rate and the initial level of the product. Conditional beta convergence occurs when each economy converges to its own steady state.

It should be noted that economies converge only if the specific factors of the steady state, which they are moving towards, are considered. Conditionality is expressed by introducing determinant variables in the model, which are defined as control variables, that is, proxies of the steady state that collect the fundamental differences between regions are used. In addition, conditionality treats the steady states of regions as unobservable and fixed over the period analysed.

The data to apply the analysis were obtained from four sources, according to the following (Table 1): 
Table 1. Description of the variables.

\begin{tabular}{|c|c|c|}
\hline Variables & Unit of Measurement & Source \\
\hline $\begin{array}{l}\text { Provincial Gross Added Value (GVAp), 1993, 1996, } \\
\text { 1999, 2001-2015. The information of the rest of years } \\
\text { was interpolated (linear method). }\end{array}$ & Millions of dollars of 2007. & \multirow[t]{3}{*}{$\begin{array}{l}\text { Central Bank of } \\
\text { Ecuador (CBE) [63-66] }\end{array}$} \\
\hline $\begin{array}{l}\text { Gross Value Added (GVA) manufacturing, years } \\
\text { 2007-2015. }\end{array}$ & Millions of dollars of 2007. & \\
\hline $\begin{array}{l}\text { Provincial Capital Expenditure of the Municipal and } \\
\text { Provincial Councils for the period 2001-2013 (annual). }\end{array}$ & Thousands of dollars of 2007. & \\
\hline $\begin{array}{l}\text { Total Population and Economically Active Population } \\
\text { (EAP) greater than } 12 \text { years. Interpolated and projected } \\
\text { data, based on census information. }\end{array}$ & Thousands of people & $\begin{array}{l}\text { National Institute of } \\
\text { Statistics and Censuses } \\
\text { (Ecuador)-INEC [67] }\end{array}$ \\
\hline $\begin{array}{l}\text { Provincial capital expenditure on education for the } \\
\text { period 2001-2015. (Annual) }\end{array}$ & Thousands of dollars of 2007. & $\begin{array}{l}\text { Ministry of Economy } \\
\text { and Finance. [68] }\end{array}$ \\
\hline
\end{tabular}

Source: The authors.

\section{Econometric Specification of Convergence}

In this case, the conditional beta convergence per capita and in productivity (measured by the ratio between Gross Value Added and Economically Active Population over 12 years) of the 22 Ecuadorian provinces in the 2001-2015 period will be "restricted" by the expenditure of annual capital of Municipal and Provincial Councils by province. This is mainly used for the formation of physical capital in infrastructure (as a proxy for public expenditure on physical infrastructure), the annual capital expenditure of the Ministry of Education (as a proxy of public expenditure on education) and a variable that measures the importance of manufacturing Gross Value Added (GVA) in regional growth. The econometric techniques that will be used will be: "traditional" linear panel: pool versus fixed effects vs random effects and dynamic panel by spatial fixed effects (Durbín Watson). The general specification of the model to be estimated is the following:

$$
\ln \frac{Y_{i, t}}{Y_{i, t-1}}=\alpha_{i t}-\beta_{0} \operatorname{lvp} c_{i t}+\beta_{1} \operatorname{lgct}_{i t}+\beta_{2} \operatorname{leduc}_{i t}+\beta_{3} \operatorname{lman}_{i t}+\varepsilon_{i t}^{*}
$$

Considering the property of the logarithms, the specification could be expressed as follows:

$$
\ln Y_{i, t}-\ln Y_{i, t-1}=\alpha_{i t}-\beta_{0} \operatorname{lvp} c_{i t}+\beta_{1} \operatorname{lgct} t_{i t}+\beta_{2} \operatorname{leduc} i t+\beta_{3} \operatorname{lman}_{i t}+\varepsilon_{i t}^{*}
$$

Assigning the denomination "tcv" and "tcp" to the difference of the left side of (6), we have the following expressions:

$$
\begin{aligned}
& t c v_{i t}=\alpha_{i t}-\beta_{0} l v p c_{i t}+\beta_{1} \operatorname{lgct}_{i t}+\beta_{2} l e d u c_{i t}+\beta_{3} \operatorname{lman}_{i t}+\varepsilon_{i t}^{*} \\
& t c p_{i t}=\alpha_{i t}-\beta_{0} l v p c_{i t}+\beta_{1} \operatorname{lgct} t_{i t}+\beta_{2} l e d u c_{i t}+\beta_{3} \operatorname{lman}_{i t}+\varepsilon_{i t}^{*}
\end{aligned}
$$

where the subscripts $i$ and $t$, refer to the model considering regions and years, respectively; $t c v$, corresponds to the difference between the natural logarithm of the non-oil per capita GVA of the last year and the natural logarithm of the non-oil per capita GVA of the last year, at provincial level: Convergence per capital; $t c p$, corresponds to the difference between the natural logarithm of productivity of the last year and the natural logarithm of productivity of the last year, at provincial level: Convergence in productivity; $\alpha_{i t}$, is the intercept; $v p c$, is the non-oil GVA of the previous year. In the context of the convergence model, they are the initial productive conditions of each province; $\beta_{0}$, is the parameter that measures economic convergence, through a negative statistical significance; $\beta_{1}, \beta_{2}, \beta_{3}$, are the coefficients of the conditioning variables of the provincial convergence process; $\operatorname{lgct}{ }_{i}$, corresponds to the logarithm of the annual capital expenditure of the Municipal and Provincial 
Councils by province; $l e d u c_{i}$, corresponds to the logarithm of annual capital expenditure on education by province; celman, is a variable that includes the impact of regional manufacturing GVA on the convergence process from 2001. The error composed of the estimation (or innovations) is the result of the multiplication of a dichotomous variable that assigns a value of " 1 " to the data corresponding to the 2007-2015 period and of " 0 " to those corresponding to the 2001-2006 period and the value of the manufacturing GVA, at provincial level and $\varepsilon^{*}$ it .

On the other hand, the specifications of the Spatial Model for convergence per capita and in productivity are as follows:

$$
\begin{aligned}
& t c v_{i t}=\alpha_{i t}+\rho W t c v_{i t}+\beta_{0} l v p c_{i t}+\beta_{1} \operatorname{lgct}_{i t}+\beta_{2} l e d u c_{i t}+\beta_{3} \operatorname{lman}_{i t}+\theta W X_{i t}+\varepsilon_{i t}^{*} \\
& t c p_{i t}=\alpha_{i t}+\rho W t c v_{i t}+\beta_{0} l v p c_{i t}+\beta_{1} \operatorname{lgct}_{i t}+\beta_{2} l e d u c_{i t}+\beta_{3} l m a n_{i t}+\theta W X_{i t}+\varepsilon_{i t}^{*}
\end{aligned}
$$

where the variables and parameters that are added to the Expressions (7) and (8) are: $p$, which is the spatial correlation coefficient related to the dependent variable: $t c v(t c p) ; W$, which is the spatial weight matrix "queen" type and $\theta$, is the spatial correlation coefficient related to the matrix of dependent variables of the model: $X_{i t}$.

Expressions (9) and (10) include the incidence of spatial contiguity or the distance between the provinces in the estimation of convergence per capita and convergence in productivity, respectively. In other words, the Spatial Model will "approximate" the existence of a "spatial" correlation process in the convergence model, at provincial level. The results of the estimations of (9) and (10) are shown in Table 2.

Table 2. Results of the Cross-sectionally augmented Im-Pesaran- Shin (IPS) test for unit roots in panel

\begin{tabular}{|c|c|c|c|c|c|c|}
\hline Variable & “tcv" & "tcp" & "lvpc" & "lgct" & "leduc" & "lman" \\
\hline \multirow{2}{*}{$\begin{array}{l}\text { With constant and } \\
\text { trend }(\text { Lag order }=2)\end{array}$} & $\begin{array}{l}\text { CIPS }{ }^{a} \text { test } \\
=-2.2502\end{array}$ & $\begin{array}{c}\text { CIPS test }= \\
-2.7109\end{array}$ & $\begin{array}{l}\text { CIPS test }= \\
-3.5004\end{array}$ & $\begin{array}{c}\text { CIPS test }= \\
-14.45\end{array}$ & $\begin{array}{c}\text { CIPS test }= \\
-27.284\end{array}$ & $\begin{array}{c}\text { CIPS test }= \\
-5.0494\end{array}$ \\
\hline & $\begin{array}{c}p \text {-value }= \\
0.1\end{array}$ & $\begin{array}{c}p \text {-value }= \\
0.1\end{array}$ & $\begin{array}{c}p \text {-value }= \\
0.01\end{array}$ & $\begin{array}{c}p \text {-value }= \\
0.01\end{array}$ & $\begin{array}{c}p \text {-value }= \\
0.01\end{array}$ & $\begin{array}{c}p \text {-value }= \\
0.01\end{array}$ \\
\hline \multirow{2}{*}{$\begin{array}{l}\text { With constant and } \\
\text { without tendency } \\
(\text { Lag order }=2)\end{array}$} & $\begin{array}{c}\text { CIPS test }= \\
-3.0087\end{array}$ & $\begin{array}{c}\text { CIPS test }= \\
-2.9464\end{array}$ & & & & \\
\hline & $\begin{array}{c}p \text {-value } \\
0.01\end{array}$ & $\begin{array}{c}p \text {-value }= \\
0.01\end{array}$ & & & & \\
\hline
\end{tabular}
models *.

* In the unit root test: the "from general to particular" method is used; ${ }^{\text {a }}$ The robust version of Im-Pesaran-Shin (IPS) unit root test for panel models is used, which considers the possible presence of cross section dependence;

${ }^{\mathrm{b}}$ It should be noted that, in most cases, the $p$-value presented is 0.1 or 0.01 given that they are the limits imposed by the test; however, the value of 0.01 is sufficient to accept the alternative hypothesis. Source: The authors.

\section{Results and Analysis}

\subsection{Convergence Model}

Firstly, the conditional convergence model is estimated using the traditional panel data method, both for convergence per capita and in productivity. Before performing the estimation, tests are carried out that justify the use of a panel model. A unit root test is performed to check the presence of stationary panels; then a "pooling" test is carried out to determine the suitability of the use of the panel data methodology in the study of economic convergence per capita and in productivity for Ecuadorian regions; and finally the Hausman test is carried out to establish the relevance of an econometric estimation that allows for correlation between the constant term $\left(\alpha_{i}\right)$ and regressors $\left(x_{i t}\right)$ : fixed effects, or one where there is no such correlation: random effects (Table 2).

Regarding the unit root test, the results of Table 2 show a $p$-value lower than 0.05 in some of the variants of this test, for all the variables analysed. Then, the null hypothesis that the panels contain unit 
roots is rejected and the alternative hypothesis that the panels are stationary is accepted. Therefore, there is evidence that the relationship to be estimated is not untrue.

On the other hand, regarding the relevance of the use of the panel data methodology, the results are shown in Table 3. First, given that the p-value of the pooling test, both in the convergence per capita model and in the convergence in productivity model, is much lower than 0.05 , the null hypothesis that there is homogeneity among the individuals of the panel and the alternative hypothesis that there is heterogeneity among the panel members is accepted. The correct model is the fixed effects panel model. Therefore, the models that must be estimated are fixed effects panel models, which will allow to estimate the "unobservable" effects among Ecuadorian provinces.

Table 3. Results of the "Pooling" test and the Hausman test.

\begin{tabular}{cccc}
\hline \multicolumn{2}{c}{ Pooling } & \multicolumn{2}{c}{ Hausman } \\
\hline Convergence per capita & Convergence in productivity & $\begin{array}{c}\text { Convergence per } \\
\text { capita } \\
\text { chisq }=15.889,\end{array}$ & $\begin{array}{c}\text { Convergence in } \\
\text { productivity } \\
\text { chisq }=15.15,\end{array}$ \\
$\mathrm{~F}=3.1978, \mathrm{df} 1=21, \mathrm{df} 2=226$, & $\mathrm{F}=2.7313, \mathrm{df} 1=22$, & $\mathrm{df}=226$, & $\mathrm{df}=4$, \\
$p$-value $=8.41 \times 10^{-6}$ & $p$-value $=0.0001285$ & $p$-value $=0.003172$ & $p$-value $=0.004582$ \\
\hline
\end{tabular}

Source: The authors.

Finally, with regard to the Hausman test, given that the $p$-value of this test, both in the convergence per capita model and in the convergence in productivity model, is less than 0.05 , the null hypothesis is rejected, which states that the difference in the coefficients is not systematic and that the correct model is the random effects model and the alternative hypothesis is accepted, according to which the difference in the coefficients is systematic. Therefore, the correct model is the fixed effects model.

These results corroborate the relevance of the use of the Panel Model with Fixed Effects, since as Evans and Karras [69] point out that econometric estimation of convergence by Ordinary Least Squares (OLS) generates consistent estimators, only if the disruption term is not correlated with the initial level of per capita product. In addition, as indicated by Andrés, Boscá and Doménech [70], Quah [71], Pritchett [72] and Durlauf and Johnson [73], in the convergence estimation, the particularities of each economy must be included in order to analyse the heterogeneity of growth factors more precisely. Table 4 shows the convergence estimations with fixed effects, per capita and in productivity.

The fulfilment of the hypothesis of conditional beta convergence per capita (EFpc) and in productivity (EFprod) is observed, given the statistical significance and the negative sign of the "lvpc" variable; the positive and statistically significant contribution of the variables: "leduc" and "lman" and "lgct" (only in the convergence per capita) to the provincial convergence process of the 2001-2015 period. On the other hand, the two estimations show an adjusted $\mathrm{R}^{2}$ greater than 0.38 , although the estimation of convergence per capita is the best fit, according to the results of the Akaike Information Criterion (AIC) and Bayesian Information Criterion (BIC). Considering the above, it can be mentioned that in the context of a Panel Model with Fixed Effects without considering space, in the 2001-2015 period the capital expenditure on education and infrastructure and the GVA of the manufacturing industries generated a process of convergence per capita and in productivity at provincial level. 
Table 4. Panel estimate with fixed effects of convergence per capita and in productivity.

\begin{tabular}{|c|c|c|}
\hline & EFpc & EFprod \\
\hline \multirow{2}{*}{$l o p c$} & $-0.211^{* * *}$ & $-0.213^{* * *}$ \\
\hline & (0.0190) & $(0.0186)$ \\
\hline \multirow{2}{*}{ lgct } & 0.0126 * & 0.00899 \\
\hline & $(0.00634)$ & $(0.00621)$ \\
\hline \multirow{2}{*}{ leduc } & $0.0112 * * *$ & $0.0125^{* * *}$ \\
\hline & $(0.00301)$ & $(0.00294)$ \\
\hline \multirow{2}{*}{ Iman } & $0.00568 * * *$ & $0.00562 * * *$ \\
\hline & $(0.000720)$ & $(0.000704)$ \\
\hline \multirow{2}{*}{ Constant } & $1.265^{* * *}$ & $1.341^{* * *}$ \\
\hline & $(0.185)$ & $(0.181)$ \\
\hline Observations & 330 & 330 \\
\hline Adjusted $\mathrm{R}^{2}$ & 0.383 & 0.393 \\
\hline$A I C$ & -1031.0 & -1045.4 \\
\hline$B I C$ & -1012.0 & -1026.4 \\
\hline
\end{tabular}

\subsection{Panel Model with Fixed Effects}

Although panel models with fixed effects enable to observe unobservable individual fixed effects of the provincial convergence process, they have some problems of heteroscedasticity, serial correlation, and contemporary or cross-sectional correlation. For this reason, as follows, Table 5 shows the results of some diagnostic tests applied in order to corroborate the consistency of the estimations.

Table 5. Diagnostic tests for panel models with fixed effects.

\begin{tabular}{|c|c|c|}
\hline Tests & Convergence Per Capita & Convergence in Productivity \\
\hline \multirow{2}{*}{$\begin{array}{l}\text { Heteroskedasticity test of } \\
\text { Breusch-Pagan [74] }\end{array}$} & $\mathrm{BP}=30.915, \mathrm{df}=4$ & $\mathrm{BP}=28.003, \mathrm{df}=4$ \\
\hline & $p$-value $=3.187 \times 10^{-6}$ & $p$-value $=1.245 \times 10^{-5}$ \\
\hline \multirow{2}{*}{$\begin{array}{l}\text { Wooldridge test of serial correlation AR (1) } \\
\text { for fixed-effect panel models [75] }\end{array}$} & chisq $=1.9043$ & chisq $=1.573$ \\
\hline & $p$-value $=0.1676$ & $p$-value $=0.2098$ \\
\hline \multirow{2}{*}{$\begin{array}{l}\text { Breusch and Pagan Lagrangian multiplier } \\
\text { test, for dependence in cross section [74] }\end{array}$} & chisq $=392.4, \mathrm{df}=231$ & chisq $=395.95, \mathrm{df}=231$ \\
\hline & $p$-value $=1.754 \times 10^{-10}$ & $p$-value $=8.231 \times 10^{-11}$ \\
\hline
\end{tabular}

Source: The authors.

The Heteroscedasticity test of Breusch-Pagan [74] fits a linear regression model to the residuals of a linear regression model (by default the same explanatory variables are taken as in the main regression model), rejecting the null hypothesis if most of the variance is explained by the additional explanatory variables. Considering that, the $p$-value, both in the convergence per capita model and in the convergence in productivity model, is much lower than 0.05 , the null hypothesis that the residuals are homoscedastic is rejected and the alternative hypothesis that the residuals are heteroscedastic is accepted. Therefore, there is statistical evidence to accept a heteroscedasticity problem in the estimation.

The Wooldridge Test of serial correlation AR (1) for panel models with fixed effects performs a serial correlation test on the panel data model, but considering unobservable individual effects. To do so, it estimates a serial correlation test type AR (1) "pool" in the residuals, using the covariance matrix and the Arellano method in order to "control" serial correlation better. The advantage of this test is that it shows consistent results with "short" panels and is robust to general heteroscedasticity. 
Considering that the $p$-value, both in the convergence model per capita and in the convergence model in productivity, is greater than 0.05 , the alternative hypothesis (the existence of serial autocorrelation type AR (1)) is rejected and the null hypothesis is accepted of non-serial autocorrelation type AR (1) in the idiosyncratic errors of the estimation with fixed effects. Therefore, there is statistical evidence that there is no serial autocorrelation type AR (1) in the idiosyncratic errors of the estimations.

Finally, the Breusch and Pagan Lagrangian multiplier test for dependence in cross section will enable to establish if the residuals are not correlated between individuals, that is, if there are no contemporary correlation problems (null hypothesis). Table 5 shows that the $p$-value, both in the convergence per capita model and in the convergence in productivity model, is less than 0.05 , so the null hypothesis is rejected and the alternative hypothesis that Estimation residuals are correlated between provinces is accepted. Therefore, there is significant evidence that there is a problem of contemporary correlation or cross section dependence. Considering the mentioned results, it is necessary to perform a convergence regression, robust to heteroscedasticity problems and contemporary correlation.

On the other hand, according to Martín [44], another of the main criticisms of "traditional" fixed effects panel models is the bias generated by possible spatial dependencies among regional economies. To deal with spatial interdependence or geographical "spillovers", in studies such as Getis and Griffith [76], Badinger, Müller and Tondl [77] and Battisti and Di Viaio [78] the estimations are made by previously identifying this interdependence through indexes such as Autocorrelation I of Moran or Geary C; others such as Rey and Montouri [79], Fingleton and Lopez-Bazo [80] or Arbia [81], that introduce a spatial "term" in the convergence equation: the spatial error term or the spatially lagged variables. In this sense, and considering the interest in analysing the impact of space on the phenomenon of regional convergence in the Ecuadorian case, a Spatial Durbin Model (sdm) will be estimated for fixed effects, with the purpose of collecting the impact of unobservable effects on the provincial convergence model per capita and in productivity. However, before this it is important to clarify that since most of the statistical packages do not estimate unbalanced spatial panels, it was decided to use Multiple Imputation Methods to replace the "missing values" and "complete" the data panels of our models of provincial convergence per capita and in productivity.

Assigning the missing values of the panel of the present investigation was done through the IBM SPSS Statistics specifying the totally conditional imputation method Monte Carlo and Iterative Markov Chain Monte Carlo (MCMC). The latter is the most appropriate when the pattern of lost data is random, the use of 10 iterations for the Markov chain, the inclusion of two-dimensional iterations (among the categorical predictor variables, which in this case are the five variables involved in the model of general convergence: " $t c v$ ", " $t c p$ ", "lvpc", "lgct", "leduc" and "lman") and Predictive Mean Matching (pmm) which is a variant of linear regression that equals the allocated values calculated by the regression model with the closest observed value.

After completely "balancing" the panels, we proceed to estimate a Spatial Durbin Model (sdm) with fixed effects, by means of the Maximum Likelihood method, considering the impact of unobservable individual fixed effects and robust standard errors grouped by provinces, in order to correct problems of heteroscedasticity and contemporary correlation and a spatial weights matrix (for more information on the spatial weights matrix, review Moreno and Vayá [82]) $W$ type "queen". Then, we proceed to estimate the Expressions (9) and (10) (Table 6). 
Table 6. Estimation Space Durbín Model (sdm), with fixed effects of the per capita convergence and in provincial productivity, in the period 2001-2015.

\begin{tabular}{|c|c|c|}
\hline & SDMpc & SDMprod \\
\hline \multicolumn{3}{|l|}{ Main } \\
\hline \multirow{2}{*}{ lopc } & $-0.237^{* * *}$ & $-0.245^{* * *}$ \\
\hline & $(0.0274)$ & $(0.0269)$ \\
\hline \multirow{2}{*}{$\lg c t$} & 0.00869 & 0.00784 \\
\hline & $(0.00927)$ & $(0.00887)$ \\
\hline \multirow{2}{*}{ leduc } & $0.00989 * *$ & $0.0107 * *$ \\
\hline & $(0.00375)$ & $(0.00378)$ \\
\hline \multirow{2}{*}{ Iman } & $0.00487^{*}$ & 0.00483 ** \\
\hline & (0.00189) & $(0.00178)$ \\
\hline \multicolumn{3}{|l|}{ Wx } \\
\hline \multirow{2}{*}{ lopc } & $0.0906^{* *}$ & $0.0927 * *$ \\
\hline & $(0.0324)$ & $(0.0332)$ \\
\hline \multirow{2}{*}{ lgct } & 0.00890 & 0.00420 \\
\hline & $(0.00867)$ & $(0.00862)$ \\
\hline \multirow{2}{*}{ leduc } & -0.00145 & 0.000163 \\
\hline & $(0.00669)$ & $(0.00650)$ \\
\hline \multirow{2}{*}{ lman } & -0.00108 & -0.00102 \\
\hline & $(0.00242)$ & $(0.00233)$ \\
\hline \multicolumn{3}{|l|}{ Spatial } \\
\hline \multirow{2}{*}{ rho } & $0.258^{* *}$ & 0.234 * \\
\hline & $(0.0913)$ & $(0.0928)$ \\
\hline \multicolumn{3}{|l|}{ Variance } \\
\hline \multirow{2}{*}{ sigma2_e } & $0.00234^{* * *}$ & $0.00226^{* * *}$ \\
\hline & $(0.000291)$ & $(0.000267)$ \\
\hline Observations & 330 & 330 \\
\hline \multicolumn{3}{|l|}{ Adjusted $\mathrm{R}^{2}$} \\
\hline$A I C$ & -1038.6 & -1050.8 \\
\hline$B I C$ & -1000.6 & -1012.8 \\
\hline
\end{tabular}

Standard errors in parentheses. ${ }^{*} p<0.1,{ }^{* *} p<0.05,{ }^{* * *} p<0.01$. Source: The authors.

The results of Table 6 confirm that the consideration of the spatial contiguity effect on the estimation of the convergence per capita model (SDMpc) and convergence in productivity (SDMprod) actually reveals a process of economic divergence at provincial level in the 2001-2015 period, given the statistical significance and the positive sign of the variable. In other words, the inclusion of space in the estimation of the convergence model shows that the annual public capital expenditure of Municipal and Provincial Councils on infrastructure contributes to increasing provincial inequalities in income (per capita) and mainly in productivity. These results may be due to the fact that the increase in public expenditure since 2007 has not been allocated efficiently to the enhancement of the productive conditions of "small" provinces, but only to the provision of "basic" equipment for the production of "primary" economic sectors. Obviously, since there is no more "precise" information regarding public expenditure on productive infrastructure at provincial level, for example, investments in strategic sectors, we must be cautious when analysing these results. 
Comparing the results of outputs 3 and 5 (specifically the results of the "Wx" section), it can be observed, on the one hand, the existence of a process of provincial economic convergence in the 2001-2015 period, both per capita and in productivity, conditioned by capital expenditure on infrastructure and the impact of manufacturing production, when the effect of spatial contiguity in the econometric estimation is not considered; and on the other hand, a process of provincial economic divergence in the same period, generated solely by capital expenditure on infrastructure (the annual provincial capital expenditure on education and the impact of manufacturing production are not statistically significant), when the effect of space on regression is considered.

These results can be constituted in the first evidence on the inefficiency of public expenditure to generate spatial (provincial) productive chains or "spillovers" in the analysed period. "Large" provinces not only continue to concentrate most of the economic activity at national level, but also continue having the highest growth rates, which allows them to maintain their status as "development poles" over time, despite the increase in public expenditure on items such as infrastructure and education, in the last almost 11 years in "small" provinces.

The foregoing should not be interpreted as a decrease in the "endogenous" potential of factors such as education and infrastructure to generate regional growth in the Ecuadorian case, but rather as an inadequate "targeting" and implementation of the public economic policy that does not allow for the generation of "spillovers" or territorial expansion of positive externalities of growth processes of large regions. The generation of regional "value chains" aimed not only at the domestic market but also at the export and "inclusion" of companies (large, medium-sized and small) of "small" provinces in these chains; effective and efficient strengthening of productive conditions of provinces through public policy; prioritization of spending in economic sectors with high added value; technification of primary activities of rural sectors; improvement of human capital of each province, "tied" to its "productive vocation"; transparent and efficient public procurement processes; generation of public-private agreements that allow for the financial sustainability of Decentralized Autonomous Governments are all included in some measures of public economic policy that would enable to generate "sustainable" spatial economic convergence processes over time.

Another interesting result of the estimation of spatial economic convergence is the non-statistical significance of the variable that includes the impact of manufacturing GVA on the convergence process of the 2001-2015 period ("Iman"). This shows that from the statistical point of view, the public policy of "changing the productive matrix" did not generate the expected results: unfortunately, the national productive matrix has not yet begun a process of transition towards activities with greater added value. On the other hand, if one considers spatial contiguity, the production and employment of the manufacturing industry generated in "large" provinces does not generate "spillovers" towards their neighbouring territories, generating processes of economic segregation at provincial level, which cause an increase in regional disparities in income and mainly in productivity.

It is also worth mentioning that the rate of conditional convergence or decrease in regional disparities remains close to $2 \%$, a level that similar investigations highlight as "standard", but decreases by approximately $30 \%$ when the contiguity effect is considered, which puts at risk, at least in the medium term, the generation of a process of regional economic convergence in Ecuador. Finally, it should be noted that the statistical significance of the spatial rho $(p)$, or the spatial correlation coefficient associated with the dependent variable, both in the convergence per capita model and in the convergence in productivity model (output 2), justify the use of a spatial econometric model due to the importance of the impact of space on regional economic convergence processes.

\section{Conclusions}

In the "traditional" econometric estimations of the model of provincial convergence per capita and in productivity, the fulfilment of the conditional beta convergence hypothesis is confirmed, given the negative sign and the statistical significance of the coefficient of the initial non-oil per capita GVA logarithm $(l v p c)$ in all cases. 
In the context of Panel Model with Fixed Effects, the positive and statistically significant "incidence" of annual capital expenditure of Municipal and Provincial Councils is recognized, as well as the variable that collects the incidence of manufacturing GVA, confirming the importance of public expenditure in the improvement of the productive infrastructure in the provincial convergence process. Considering the results of the Spatial Durbin Model with fixed effects, the positive and statistically significant "incidence" of the logarithm of the annual capital expenditure of Municipal Councils in the process of provincial divergence is recognized. It is also observed that the rate of conditional convergence varies according to the methodology used: in the "conventional" method with fixed effects a speed close to $2 \%$ is obtained and the Spatial Durbin Model decreases approximately $43 \%$. This shows that the inclusion of a temporal autoregressive process of a dependent variable generates a more "relevant" and "efficient" estimation of the convergence speed.

It must be recognized that the high inequality of "initial endowments" contributed to a process of conditional convergence of each economy towards its own steady state, led by the territories considered as "growth poles" and characterized by a decreasing trend; and that an increase in public expenditure was not enough to increase the level of productivity of the economy at regional level in the 2001-2015 period, given the better results of the convergence per capita model.

It is corroborated that the inclusion of the spatial contiguity effect provides a more suitable econometric treatment for the generation of geographic "spillovers" in the process of economic convergence. This type of estimation shows the overestimation of the convergence speed of "traditional" panel models with fixed effects.

The results show a persistence of asymmetries in the sub-national spaces of Ecuador, the criteria of profitability and agglomeration establish that capital (including foreign investment) and work will be aimed at prosperous areas. For this reason, regional state policies are essential to correct these imbalances.

However, these "differentiated" territorial policies should not be confused with welfare and sectorial policies. The traditional policies to fight poverty do not incorporate regional dimensions, typical of each territory, which means that they have a low impact on the poorest areas. And the other hand, the sectorial policies of the central government, based on investment decisions in major infrastructure projects, most of the time due to political expediency, are not designed to gradually overcome the structural heterogeneity of provinces. For this reason, these sectorial policies did not allow to diversify the productive structure, taking into account the potential of the territories and generating new pillars for growth.

There are several examples and instruments of regional policy that the government of Ecuador could adapt. Undoubtedly, the regional policy of the European Union is the main reference in this area. The operation and implementation of Structural Funds and Cohesion Funds can serve as a guidance at national scale, equivalent to a Regional Compensation Fund, to prioritize investments in deprived areas and reduce disparities between regions, promoting balanced development in provinces.

Another pending issue in Ecuador is to achieve an effective decentralization of investment resources by territorial units; the budgets and execution of works still respond to central interests and planning. The "regionalization" of the country was also incomplete, the latter would allow for regions to have models that articulate territorial elements that denote their potential.

Finally, it should be noted that among the limitations that did not allow to obtain more conclusive economic relations between public spending and provincial economic convergence, are the limited availability of production information and public spending for a long time series, at provincial level; a lack of disaggregation or characterization of public expenditure at provincial level and a lack of information on national and foreign private investment for a long time series, at provincial level, which would also enable to study the impact of the private productive sector on the growth process and economic convergence at regional level in Ecuador, which are restrictions that are expected to be overcome in future investigations. 
Author Contributions: Investigation, Methodology, Formal Analysis, Resources, and Writing-review and editing, J.F.-C., R.C.-Q., J.A.-G., M.d.l.C.d.R.-R.; Administration and Supervision, J.A.-G. and M.d.l.C.d.R.-R.

Funding: This research received no external funding.

Conflicts of Interest: The authors declare no conflict of interest.

\section{References}

1. Correa-Quezada, R.C. Las políticas de desarrollo regional en Ecuador. Yachana Revista Científica 2017, 5, 150-165.

2. Aschauer, D.A. Highway capacity and economic growth. Econ. Perspect. 1990, 14, 4-24.

3. Cancelo de la Torre, J.R.; Uriz Tomé, P. Una metodología general para la elaboración de índices complejos de dotación de infraestructuras. Estudios Regionales 1994, 40, 167-188.

4. SELA, Sistema Económico Latinoamericano y del Carribe. Definiendo las asimetrías en América Latina y el Caribe. Un enfoque cuantitativo. Caracas, Venezuela Noviembre de 2016 SP/Di No. 4-16. Available online: http:/ / www.sela.org/media/2463949/definiendo-las-asimetrias-en-alc.pdf (accessed on 01 January 2018).

5. Sánchez, R. Desarrollo de Infraestructura y Crecimiento Económico: Revisión Conceptual; Naciones Unidas Comisión Económica para América Latina y el Caribe (CEPAL): Santiago de Chile, Chile, 2004; Volume 75.

6. Tomassian, G. Infraestructura Física e Integración Regional; Boletín FIAL. Edición No. 280, diciembre; Naciones Unidas Comisión Económica para América Latina y el Caribe (CEPAL): Santiago de Chile, Chile, 2009.

7. Ponce Jarrín, J. La Vivienda y la Infraestructura Básica en el Ecuador 1990-2001. Secretaría Técnica del Frente Social. Sistema integrado de Indicadores Sociales del Ecuador. Quito. Jornadas Iberoamericanas sobre Hábitat evolutivo y producción social del Hábitat, Tecnologías y herramientas de Apoyo. Cartagena de Indias, Colombia. 2002. Available online: http://www.siise.gob.ec/siiseweb/PageWebs/pubsii/pubsii_0011.pdf (accessed on 10 January 2018).

8. Vilema, F. Infraestructura de Transporte y Comercio: Un Análisis Comparativo Entre Ecuador y Países de Asia-Pacifico. ESPOL; Grupo de Investigación \& Docencia Económica (GRIDE). 2010. Available online: http://www. ceap.espol.edu.ec/sites/ceap.espol.edu.ec/files/vilema_2010_reporte3_piceap2.pdf (accessed on 10 January 2018).

9. Oleas, S. Infraestructura de utilidad pública en salud y educación y pobraza en el Ecuador. Inversión en infraestructura pública y reducción de la pobreza en América Latina; Instituto Konrad Adenauer Stiftung: Sankt Augustin, Germany, 2011.

10. Solow, R. A contribution to the theory of economic growth. Quat. J. Econ. 1956, 70, 65-94. [CrossRef]

11. Swan, T. Economic growth and capital accumulation. Econ. Rec. 1956, 82, 755-782. [CrossRef]

12. Mora, A.J. Sobre Convergencia Económica: Aspectos Teóricos y Análisis Empírico para las Regiones Europeas y Españolas. Doctoral Thesis, Universitat de Barcelona, Cataluña, Spain, 2003. Available online: http:/ / diposit.ub.edu/dspace/handle/2445/35333 (accessed on 10 February 2018).

13. Romer, P. Increasing returns and long-run growth. J. Polit. Econ. 1986, 94, 1002-1037. [CrossRef]

14. Romer, P. Endogenous technological change. J. Polit. Econ. 1990, 98, 71-102. [CrossRef]

15. Lucas, R., Jr. On the mechanics of economic development. J. Monet. Econ. 1988, 22, 3-42. [CrossRef]

16. Arrow, K. The economic implications of learning by doing. Rev. Econ. Stud. 1962, 29, 155-173. [CrossRef]

17. Van der Ploeg, F.; Tang, P.J.G. The macroeconomics of growth: An international perspective. Oxford Rev. Econ. Policy 1992, 8, 15-28. [CrossRef]

18. Rebelo, S. Long-run policy analysis and long-run growth. J. Polit. Econ. 1991, 99, 500-521. [CrossRef]

19. Aguirre, F. El Estado y la Inversión en Infraestructura: Sus Efectos Sobre las Dinámicas Territoriales; Rimisp-Centro Latinoamericano de Desarrollo Rural: Santiago de Chile, Chile, 2012.

20. Bustillos, B.; Alonso, H.; Gutiérrez Flores, L. La importancia de la infraestructura física en el crecimiento económico de los municipios de la frontera norte. Estudios Front. 2012, 13, 57-88.

21. Harrod, R.F. An essay in dynamic theory. Econ. J. 1939, 49, 14-33. [CrossRef]

22. Domar, E. Capital expansion, rate of growth, and employment. Econometrica 1946, 14, 137-147. [CrossRef]

23. Kaldor, N. Marginal productivity and the macro-economic theories of distribution: Comment on Samuelson and Modigliani. Rev. Econ. Stud. 1966, 33, 309-319. [CrossRef]

24. Hicks, J.R. The Theory of Wages, 2nd ed.; Macmillan: London, UK, 1963.

25. Robinson, J. Collected Economic Papers; Basil Blackwell: Oxford, UK, 1973; Volume IV. 
26. Robinson, J. History Versus Equilibrium. In Robinson, J. Collected Economic Papers; Basil Blackwell: Oxford, UK, 1979; Volume V.

27. Arrow, K.J.; Kurz, M. Public Investment, the Rate of Return and Optimal Fiscal Policy; Johns Hopkins University: Baltimore, MD, USA, 1970.

28. Weitzman, M.L. Aggregation and Disaggregation in the Pure Theory of Capital and Growth: A New Parable (No. 292), Cowles Foundation for Research in Economics: Yale University, NH, USA, 1970.

29. Becerril Torres, O.U.; Álvarez Ayuso, I.C.; del Moral Barrera, L.E.; Vergara González, R. Indicador de infraestructuras productivas por entidad federativa en México, 1970-2003. Gestión y Política Pública 2009, 18, 379-438.

30. Barro, R.J. The persistence of unemployment. Am. Econ. Rev. 1988, 78, 32-37.

31. Barro, R.J.; Sala-i-Martin, X. Technological Diffusion, Convergence, and Growth (No. w5151); National Bureau of Economic Research: Cambridge, MA, USA, 1995.

32. Wadley, D. Estrategias de desarrollo regional. Papeles de Economía Española 1988, 35, 96-114.

33. Holtz-Eakin, D.; Lovely, M.E. Scale Economies, Returns to Variety and the Productivity of Public Infrastructure. Reg. Sci. Urban Econ. 1996, 26, 105-123. [CrossRef]

34. Fujita, M.; Krugman, P.; Venables, A.J. The Spatial Economy: Cities, Regions and International Trade; MIT Press: London, UK, 1999.

35. Rietveld, P.; Nijkamp, P. Transport Infrastructure and regional development. In Analytical Transport Economics. An International Perspective; Polak, J.B., Heertje, A., Eds.; Edward Elgar: Cheltenham/Northampton, UK, 2000; pp. 208-232.

36. Berechman, J. Transport investment and economic development: Is there a link. Transp. Econ. Dev. Round Table 2002, 119, 103-138.

37. Rostow, W. The Stages of Economic Growth: A Non-Communist Manifesto; Cambridge: Cambridge, UK, 1961.

38. Taaffe, E.J.; Morrill, R.L.; Gould, P.R. Transport expansion in underdeveloped countries: A comparative analysis. Geogr. Rev. 1963, 53, 503-529. [CrossRef]

39. Barro, R.J. Government spending in a simple model of endogeneous growth. J. Polit. Econ. 1990, 98, S103-S125. [CrossRef]

40. Helliwell, J.F.; Chung, A. Convergence and Growth Linkages between North and South; NBER Working Paper No. 3948; MA National Bureau of Economic Research: Cambridge, UK, 1992.

41. Piedrahita, A.R. Crecimiento económico en la América Latina. Estudio basado en el modelo neoclásico. El Trimestre Económico 1998, 65, 339-362.

42. Utrera, G. El crecimiento económico en Latinoamérica. In Anales de la XXXV Reunión Anual de la Asociación Argentina de Economía Política; Universidad Nacional de Córdoba: Buenos Aires, Argentina, 1999.

43. Mendoza, J.E. Apertura, gasto público y convergencia en América Latina: Un análisis econométrico espacial. Comercio Exterior 2007, 57, 705-717.

44. Martín, F. Convergencia en América Latina. Un Análisis Dinámico. Documentos de trabajo del Instituto Interuniversitario de Iberoamérica 2010. DT 02/2010. Available online: https://gredos.usal.es/jspui/ bitstream/10366/75413/1/DT_02_2010.pdf (accessed on 11 February 2018).

45. Rodríguez, D.; López, F.; Mendoza, M.Á. Revisión de la hipótesis de convergencia mediante cointegración en panel: El caso de América Latina. Economía: Teoría y Práctica 2016, 44, 51-82.

46. Utrera, G.E.; Koroch, J.A. Convergencia: Evidencia empirica para las provincias argentinas (1953-1994). In Proceedings of the Anales de la XXXIIIa Reunión Anual de la Asociación Argentina de Economia Poltica, Universidad Nacional de Cuyo Mendoza, Mendoza, Argentina, 11-13 November 1998.

47. Garrido, N.; Marina, A.; Sotelsek, D. Dinámica de la distribución del producto a través de las provincias argentinas (1970-1995). Estudios Econ. Apl. 2002, 20, 123-140.

48. Bonet, J.; Meisel, A. La Convergencia Regional en Colombia: Una Visión de Largo Plazo, $1926-1995$. Coyunt. Econ. 2001, 29, 69-106.

49. Morandé, F.; Soto, R.; Pincheira, P. Achilles, the Tortoise, and Regional Growth in Chile. Análisis empírico del crecimiento en Chile. In Estudios Empíricos sobre el Crecimiento en Chile; Morandé, F., Vergara, R., Eds.; CEP-Ilades-Georgetown University: Washington, DC, USA, 1997; pp. 141-170.

50. Barro, R.; Sala-i-Martín, X. Convergence across states and regions. Brook. Papers Econ. Act. 1991, 1, 107-182. [CrossRef]

51. Bernard, A.B.; Durlauf, S.N. Convergence in international output. J. Appl. Econ. 1995, 10, 97-108. [CrossRef] 
52. Canova, F.; Marcet, A. The Poor Stay Poor: Non-convergence across Countries and Regions (No. 1265). CEPR Discussion Papers. 1995. Available online: https:/ / papers.ssrn.com/sol3/papers.cfm?abstract_id=289497 (accessed on 19 February 2018).

53. Willington, M. Un análisis empírico del crecimiento económico regional en Argentina. Documento de Trabajo 84; Instituto de Estudios Económicos sobre la Realidad Argentina y Latinoamericana (IEERAL); Fundación Mediterránea: Córdoba, Argentina, 1998.

54. Chacón, S.K.; Paredes, D.A. Desigualdad espacial de ingresos en Chile y su relación con la concentración de capital humano. El Trimestre Econ. 2015, 82, 351-377. [CrossRef]

55. Vergara, R.; Mejía, J.; Martínez, A. Crecimiento económico y convergencia regional en el Estado de México. Paradig. Econ. 2010, 1, 53-88.

56. Mendoza, M.A.; Valdivia, M. Remesas, crecimiento y convergencia regional en México: Aproximación con un modelo panel-espacial. Estudios Econ. 2016, 31, 125-167.

57. Ramón-Mendieta, M.G.; Ochoa-Moreno, W.S.; Ochoa-Jiménez, D.A. Growth, Clusters, and Convergence in Ecuador: 1993-2011. In Regional Problems and Policies in Latin America; Springer: Berlin/Heidelberg, Germany, 2013; pp. 323-337.

58. Ramón-Mendieta, M.; Quintana-Romero, L. Convergencia y divergencia regional en Ecuador. In Regiones y Economía en el Ecuador: Crecimiento, Industria, Migración y Empleo; Quintana, L., Mendoza, M.A., Correa-Quezada, R., Coord., Eds.; Abya-Yala: Quito, Ecuador, 2014; pp. 85-105.

59. Quintana-Romero, L.; Mendoza, M.A.; Correa-Quezada, R. Las regiones ecuatorianas en el contexto Latinoamericano. In Regiones y Economía en el Ecuador: Crecimiento, Industria, Migración y Empleo; Quintana, L., Mendoza, M.A., Correa-Quezada, R., Coord., Eds.; Abya-Yala: Quito, Ecuador, 2014; pp. 13-27.

60. Mendieta-Muñoz, R.M. La hipótesis de la convergencia condicional en Ecuador: Un análisis a nivel cantonal. Retos 2015, 5, 13-25. [CrossRef]

61. Aguilar Apolo, C.; Correa Quezada, R. Dimensión territorial del potencial de desarrollo de los cantones del Ecuador. Paradig. Econ. 2016, 8, 85-110.

62. Sala-i-Martín, X. Apuntes de Crecimiento Económico, 2nd ed.; Antoni Bosch Editor: Barcelona, Spain, 2000.

63. Banco Central del Ecuador. Retropolación y Cuentas Anuales 1965-2007 [Base de datos], (s.f.). Available online: https: / / contenido.bce.fin.ec/frame.php?CNT=ARB0000023 (accessed on 12 January 2018).

64. Banco Central del Ecuador. 85 años de Información Estadística [Base de datos], (s.f.). Available online: https: / / contenido.bce.fin.ec/documentos/PublicacionesNotas/Catalogo/Anuario/80anios/indice85anios.htm (accessed on 12 January 2018).

65. Banco Central del Ecuador. Cuentas Nacionales Anuales [Base de datos], (s.f.). Available online: https: / contenido.bce.fin.ec/documentos/PublicacionesNotas/Catalogo/CuentasNacionales/Anuales / Dolares/indicecn1.htm. (accessed on 12 January 2018).

66. Banco Central del Ecuador. Cuentas Nacionales Regionales 2007-2015 [Base de datos], (s.f.). Available online: https:/ / contenido.bce.fin.ec/documentos/Estadisticas/SectorReal/CuentasProvinciales/Indice. htm. (accessed on 12 January 2018).

67. National Institute of Statistics and Censuses (Ecuador)-INEC. Censos de Población y Vivienda 2001 y 2010 [Base de datos], (s.f.). Available online: http:/ / www.ecuadorencifras.gob.ec/sistema-integrado-deconsultas-redatam/ (accessed on 12 January 2018).

68. Ministry of Economy and Finance. Estadísticas Fiscales. Available online: https://www.finanzas.gob.ec/ estadisticas-fiscales/ (accessed on 12 January 2018).

69. Evans, P.; Karras, G. Convergence revisited. J. Monet. Econ. 1996, 37, 249-265. [CrossRef]

70. Andrés, J.; Boscá, J.E.; Doménech, R. Data Fields and Convergence Regressions: Results for the OECD; Ministerio de Economía y Hacienda, Secretaría de Estado de Hacienda, Dirección General de Planificación, D-94006, Ministerio de Hacienda, Dirección General de Presupuestos: Madrid, Spain, 1994.

71. Quah, D.T. Empirical cross-section dynamics in economic growth. Eur. Econ. Rev. 1993, 37, $426-434$. [CrossRef]

72. Pritchett, L. Divergence, big time. J. Econ. Perspect. 1997, 11, 3-17. [CrossRef]

73. Durlauf, S.N.; Johnson, P.A. Multiple regimes and cross-country growth behaviour. J. Appl. Econom. 1995, 10, 365-384. [CrossRef]

74. Breusch, T.S.; Pagan, A.R. A simple test for heteroscedasticity and random coefficient variation. Econom. J. Econom. Soc. 1979, 47, 1287-1294. [CrossRef] 
75. Wooldridge, J.M. Econometric Analysis of Cross-Section and Panel Data, 2nd ed.; MIT Press: Cambridge, MA, USA, 2010.

76. Getis, A.; Griffith, D.A. Comparative spatial filtering in regression analysis. Geogr. Anal. 2002, 34, $130-140$. [CrossRef]

77. Badinger, H.; Müller, W.; Tondl, G. Regional convergence in the European Union, 1985-1999: A spatial dynamic panel analysis. Reg. Stud. 2004, 38, 241-253. [CrossRef]

78. Battisti, M.; Di Vaio, G. A spatially filtered mixture of $\beta$-convergence regressions for EU regions, $1980-2002$. Empir. Econ. 2008, 34, 105-121. [CrossRef]

79. Rey, S.J.; Montouri, B.D. US regional income convergence: A spatial econometric perspective. Reg. Stud. 1999, 33, 143-156. [CrossRef]

80. Fingleton, B.; López-Bazo, E. Empirical growth models with spatial effects. Papers Reg. Sci. 2006, 85, 177-198. [CrossRef]

81. Arbia, G. Spatial Econometrics: Statistical Foundations and Applications to Regional Convergence; Springer: Berlin, Germany, 2006.

82. Moreno, R.; Vayá, E. Técnicas Econométricas para el Tratamiento de Datos Espaciales: La Econometría Espacial; Edicions Universitat Barcelona: Cataluña, Spain, 2002.

(c) 2019 by the authors. Licensee MDPI, Basel, Switzerland. This article is an open access article distributed under the terms and conditions of the Creative Commons Attribution (CC BY) license (http:/ / creativecommons.org/licenses/by/4.0/). 